\title{
Inflammation and the Formation of Epiretinal Membranes
}

\author{
C GILBERT, P HISCOTT, W UNGER, I GRIERSON and D McLEOD \\ London
}

\begin{abstract}
Summary
In this review of the literature evidence is provided from clinical, histological and experimental sources that inflammatory processes play a central role in the pathogenesis of contractile epiretinal membranes and proliferative vitreoretinopathy.
\end{abstract}

Inflammation has been defined as "the process by means of which cells and serum accumulate about an injurious substance and tend to destroy it." Any process which injures cells can induce an inflammatory reaction, such as mechanical trauma (including surgical trauma), thermal damage (which would include cryothermy and laser photocoagulation), chemical injury, ultraviolet or $\mathrm{X}$-irradiation, ischaemic damage, infection by bacteria, viruses, parasites or fungi and injury secondary to inappropriate or excessive operation of the immune system. The tissue response to an insult involves a highly complex interaction of the vascular, haemopoetic, immune, coagulation, fibrinolytic, complement and kinin systems. For example, bacterial endotoxin which is frequently used to produce models of experimental uveitis, ${ }^{2}$ activates the coagulation cascade by activation of Hageman factor (Factor XIII), which in turn activates several other cascade reactions. Hageman factor converts plasminogen proactivator to plasminogen activator (fibrinolytic system) and prekallikrein to kallikrein (kinin system); it also activates clotting Factor XI (coagulation cascade). ${ }^{3}$ Cascade interactions may be mediated by substances derived directly from the initiating insult (such as bacterial toxin), from products of tissue damage (i.e. collagen fragments), from serum-derived protein, or by substances released from or secreted by inflammatory cells (inflammatory mediators). These interactions are important in initiating, controlling and resolving inflammation.

The inflammatory reaction has been classically defined as acute, subacute, chronic and granulomatous inflammation. When the initiating agent has been destroyed or contained, and damaged tissues removed, a healing phase emerges.

Early phases of the acute inflammatory response are characterised by vascular changes. Vasodilatation and increased vascular permeability (mediated by prostaglandins and histamine) promote extravascular accumulation of serum proteins, which results in tissue oedema. Polymorphonuclear leucocytes (PMNs) are attracted to sites of tissue damage by many substances, including serum albumen, prostaglandin $E_{1}$, denatured protein and $C 5 a$ of the complement cascade: they migrate from the capillaries into the extravascular compartment. PMNs are actively phagocytic and their function is to perform an initial debridement of the injured tissue and to initiate subsequent cellular recruitment. After one to two days, PMNs disappear from the site of inflammation and are replaced by macrophages, which are derived from circulating blood monocytes or tissue histiocytes. Chemoattractants for macrophages include microbial products, fibrin degradation

From: Pathology Department, Institute of Ophthalmology and Surgical Viteroretinal Unit, Moorfields Eye Hospital, London.

Correspondence to: Miss C E Gilbert FRCS, Pathology Department, Institute of Ophthalmology, 17-25 Cayton Street, London EC1V 9AT. 
products, lymphokines (secreted by actived $\mathrm{T}$ lymphocytes) and complement cleavage compounds. $^{4}$ Macrophages are highly specialised cells and exhibit a wide spectrum of biological activity, playing a regulatory role in organogenesis, tumour growth and chronic inflammation. $^{5}$ In acute inflammation macrophages have two main functions: to contain or eliminate the stimulus which excited the inflammatory response and to initiate a repair process. These functions can only be performed by activated macrophages and activating agents include lymphokines, immune complexes and the complement cleavage compound $\mathrm{C} 3 \mathrm{~b}$. Activation stimulates increased phagocytosis and enhanced lysosomal and secretory activity. Phagocytosis and fusion of phagosomes to lysosomes require increased metabolic activity and the associated respiratory burst generates oxygen-derived toxic free radicals. These substances are required for intracellular bacterial killing, but if released, can augment tissue damage. Activated macrophages secrete lysosomal enzymes such as collagenase, lysosome and elastase into the extracellular tissue, plus a host of biologically active compounds. Some of these, including plateletderived growth factor (PDGF), fibronectin (FN) and interleukin-1 (IL-1) play an important role in initiating the healing phase of inflammation by their modulating effects on fibroblasts. Once recruited to the site of inflammation fibroblasts proliferate and release a complex cocktail of substances into the extracellular space, including FN, glycosaminoglycans and tropocollagen. FN plays an important role in wound repair by providing a temporary scaffold for fibroblast migration, and is abundant in early wounds. Modulation of the extracellular matrix produces a collagenous scar and as the scar matures the cellular component diminishes. Contraction is a characteristic feature of scar maturation and was initially belived to be due to collagen shrinkage, but there is increasing evidence to suggest that this is a cellular process, mediated by myofibroblasts. ${ }^{6}$ Another feature of postinflammatory healing is the development of neovascularisation; proliferating capillary endothelial cells form capillary buds which invade the damaged tissues and re-establish an albeit abnormal circulation.

Epiretinal membrane (ERM) formation bears many of the features of such a wound healing process $^{7}$ and there is extensive clinical, histological and experimental evidence which supports this hypothesis.

\section{Intraocular inflammation}

Intraocular inflammation, whether in response to trauma, infection or disturbance of the immune system poses a threat to vision owing to the unique architecture of the structures required for optical transparency, photo-neural transduction and retino-cortical organisation.

The vitreoretinal surface is relatively well protected from severe trauma or exogenous infection, but is vulnerable to inflammatory damage primarily affecting the uveal tract or retinal vasculature. The inner limiting lamina (ILL) constitutes an important barrier to the movement of molecules and cells and separates the inner layers of the retina from the vitreous. The physical state of the vitreous gel, whether it remains attached to or detached from the ILL and the extent of vitreous syneresis will influence the degree to which an initially focal area of inflammation will spread to affect the vitreoretinal surface generally, by modifying inflammatory cell migration and diffusion of inflammatory mediators. The avascular gel contains histiocytes "hyalocytes" which may transform into macrophages during inflammation. ${ }^{8}$ In addition, normal vitreous plays an active and complex role in regulating the behaviour of retinal pigment epithelial cells (RPE), retinal capillary endothelial cells and dermal fibroblasts. ${ }^{9,10}$ Retinal glia, in particular Müller cells, contribute signficantly to the cellular component of ERMs, and they migrate through the ILL in response to a number of stimuli. ${ }^{11}$ Purely glial ERMs are non-contractile and therefore do not fulfill all the criteria of a wound healing process. The contribution of glia to the pathobiology of ERM formation remains unclear; they do however have phagocytic properties and may act as a scaffold for the proliferation and migration of RPE cells and the fibroblast-like cells seen in contractile membranes. ${ }^{12}$ The RPE is a stable monolayer of cells which together with Bruchs membrane provides a barrier between the sensory retina and choroid, which limits the spread of inflammatory mediated damage focused on the choroid. RPE cells migrate, proliferate or 
transform into phagocytes in a variety of situations and they contribute significantly to the cellular component of ERMs which develop in the presence of full thickness retinal breaks. ${ }^{13}$ The blood-retinal barrier (BRB) comprising the outer BRB of the RPE and the inner BRB of the retinal vasculature limits the accumulation of serum derived proteins in the sensory retina. Breakdown of the BRB secondary to inflammation or surgical trauma allows serum proteins to diffuse into the retina and vitreous cavity. Some of these, namely PDGF and FN, may play a part in augmenting the development of ERMs by their regulatory effects on $\mathrm{RPE}^{14}$ and glia. ${ }^{15}$

\section{Intraocular Inflammation and Epiretinal Membrane Formation}

Epiretinal cellular proliferations can be conveniently divided into vascularised and nonvascularised membranes. ${ }^{16}$ Vascularised ERMs generally arise in the context of inner retinal ischaemia secondary to retinal capillary nonperfusion e.g. retinal venous occlusion and diabetic retinopathy. These membranes are geldependent i.e. they appear to require the scaffolding provided by an attached vitreous gel for their development. Conversely, nonvascularised ERMs, forming a spectrum ${ }^{17}$ from simple non-contractile glial membranes to the complex, contractile ERMs of macular pucker and proliferative vitreoretinopathy (PVR) are essentially gel independent in their growth requirements. However, the distinction between vascularised and non-vascularised proliferations is considerably blurred in inflammatory eye disease. For example, disc neovascularistion may complicate chronic uveitis with no associated retinal capillary non-perfusion on fluorescein angiography; ${ }^{18}$ the deficiency in the BRB around the optic disc may be an explanation for this. Furthermore, epimacular proliferations causing macular pucker frequently have a vascular component identifiable both biomicroscopically ${ }^{19}$ and during vitrectomy and membrane peeling procedures.

Characteristic patterns of inflammatory response at the vitreoretinal juncture are seen clinically and these presumably reflect not only the nature, site and extent of the initiating event but also the activities of specific cell types and the contribution of inflammatory mediators and serum derived proteins. The inferior fundus is the most frequently affected sector in PVR and pars planitis and this may be due to gravitational effects on dispersed RPE and inflammatory cells. Macula and disc oedema are frequently seen in posterior uveitis and the increased blood flow found in these regions in association with BRB breakdown may account for this.

\section{A: Posterior Segment Trauma:}

Retinal disruption caused by posterior segment penetrating injury is generally self-sealing. The wound healing response presumably reflects the local accumulation of inflammatory cells and mediators, and the accessability of fibroblasts from the depths of the wound and the presence of a scaffold for cell migration provided by fibrin or vitreous gel. Conversely, retinal tears generated by dynamic vitreous traction are remarkable for their lack of a local repair process. This may, in part, be accounted for by the lack of a scaffold for cellular repair.

PVR complicates up to $10 \%$ of rhegmatogenous retinal detachments and risk factors include the presence of intraocular haemorrhage, uveitis, large retinal breaks exposing more than three disc diameters of RPE and failure of previous surgery. ${ }^{20}$ Some of these factors may apply in the pathogenesis of ERM formation which may be seen after severe blunt trauma (Fig 1). Surgical trauma is associated with breakdown of the BRB and excessive cryothermy can stimulate a vigorous inflammatory reaction. ${ }^{21}$ The association of epiretinal and subretinal membrane formation with the presence of RPE cells dispersed throughout the vitreous cavity suggests an important role of RPE in this process. "Anterior loop traction", i.e. that developing after inadequate basal vitrectomy, indicates that exposed vitreous matrix is also a key factor. ${ }^{22}$

\section{B: Posterior Segment Infection:}

Intraocular bacterial infection is associated with a vigorous inflammatory response and visual loss results not only from the effects of toxic products but also from the development of ERMs, with or without rhegmatogenous retinal detachment.

ERM formation is also a feature of endogenous or metastatic retinal or chorioretinal infection by toxocara, toxoplasmosis or candida endophthalmitis. Perhaps by virtue of the 
attenuated virulence of these organisms, the inflammatory changes are characteristically focal and chronic. Candidiasis in particular, results in a fibrovascular membrane response. Generalised PVR is a long term feature of viral retinitis, for example after acute retinal necrosis or cytomegalovirus infection in AIDS.

\section{C: Posterior Segment Inflammation:}

Central visual loss associated with chronic uveitis is most frequently a consequence of cystoid macular oedema, although asymptomatic ERMs are also commonly seen in these eyes. ${ }^{23}$ Glial proliferation is especially a feature of pars planitis, with "snowbanking" on the peripheral retina and pars plana; peripheral neovascularisation and macular pucker (Fig 2) are also occasionally seen. The epimacular proliferation is often more widespread than in idiopathic pucker, the membranes often have a vascular component visible clinically or detected histopathologically (Figs $3 a$ and $3 b$ ), and an exaggerated tendency to reproliferation after ERM peeling has been noted. ${ }^{7}$ Low-grade uveitis and macular pucker are also associated with peripheral retinal vascular abnormalities. ${ }^{24}$

Macular pucker is a prominent complication of retinal vasculitis whether idiopathic (Eales's Disease) or with systemic associations such as Behçet's Disease or sarcoidosis. However, the clinical picture in severe vasculitis is usually dominated by neovascularisation and fibrovas-

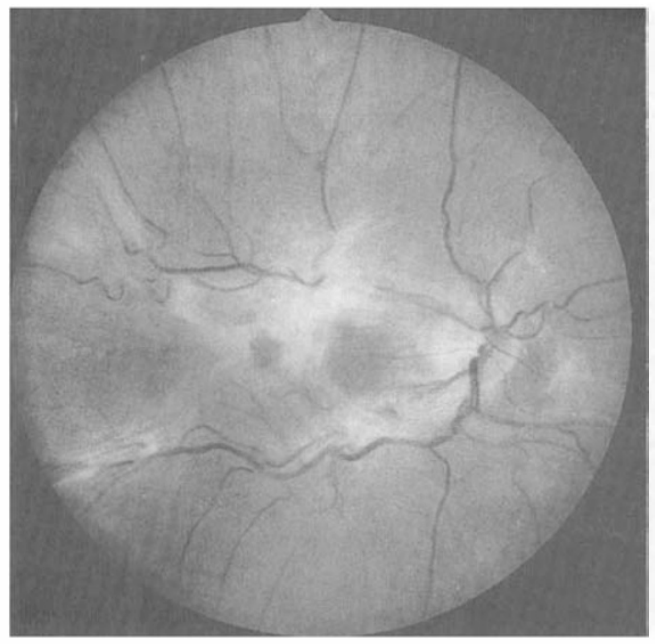

Fig. 1. Fundus photograph of an ERM complicating severe blunt trauma. cular ERM formation secondary to venous occlusion and retinal capillary non-perfusion, which may thereafter be complicated by vitreous haemorrhage and traction retinal detachment.

\section{Cellular Mediators of Inflammatory Eye Disease:}

Histologically ERMs have many features in common with healing wounds in other tissues; they contain macrophages (Fig $3 \mathrm{c}$ and 4), fibroblast-like cells and an extracellular matrix comprised of $\mathrm{FN}$ and collagen. ${ }^{25}$ Macrophages can be identified by their characteristic morphology and immunohistochemically and since the first ultrastructural report of an excised ERM $^{26}$ they have consistently been reported, frequently occurring in large numbers. ${ }^{27,28,7}$ In one study they were found in $84 \%$ of membranes ${ }^{27}$ and in another they were present in $100 \% .^{7}$ The membranes were obtained from eyes with a range of diagnoses, and macrophages together with other inflammatory cells were found to be particularly abundant in ERMs complicating pars planitis (Fig 3a-c;4). Macrophages have been found in early (less than an estimated four months duration) and late membranes. These cells are frequently observed to be undergoing autolysis and as macrophages have a limited life span and do not divide, continued recruitment to the retinal surface is implied. The origin of these cells in ERMs remains controversial; in the presence of full

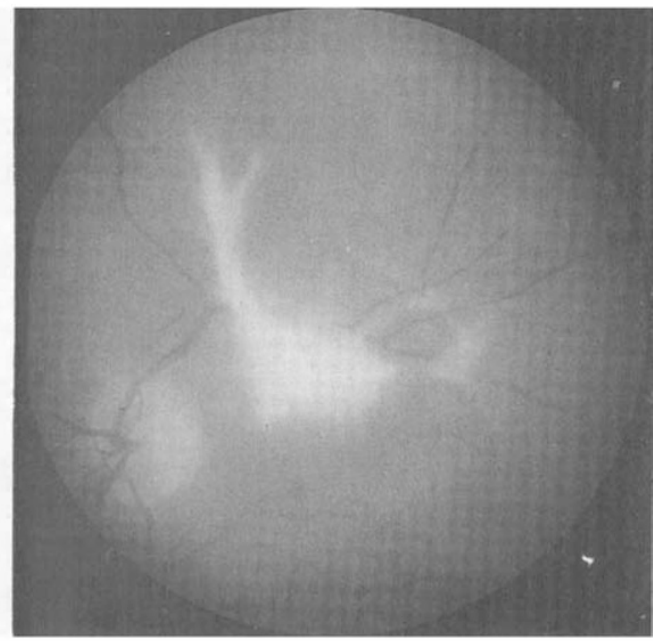

Fig. 2. Biomicroscopic photograph of an epimacular membrane in a patient with pars planitis. 
thickness retinal breaks migrating RPE cells can gain access to the vitreous cavity and retinal surface where they may transform into macrophage-like cells. ${ }^{29}$ They may also be derived from "hyalocytes" 8 and there is some evidence to suggest that they may be derived from retinal "microglia". ${ }^{30}$ Circulating blood monocytes are the main source of macrophages in inflamed tissues in other sites and the macrophages observed in ERMs could gain access to the vitreous cavity from the ciliary, ${ }^{31}$ retinal, ${ }^{32}$ or choroidal vasculature. ${ }^{29}$ Abundant macrophages have also been observed in subretinal strands removed during vitreoretinal surgery. ${ }^{33}$

Cell outgrowths have been obtained from surgically-excised ERMs maintained in tissue culture and in both studies macrophages were identified by their morphological, ${ }^{34,35}$ and locomotory 35 characteristics in every culture which produced cell monolayers. Fibroblasts, the cells which produce collagen and the other extracelluar components of scar tissue are also found in ERMs, as are myofibroblasts. ${ }^{25,27,28}$ Myofibroblasts are spindle shaped cells with smooth muscle cell characteristics. They contain actin and myosin filaments and are thought to be responsible for producing wound contracture. ${ }^{27,6}$ The origin of fibroblast-like cells in ERMs is controversial. It has been proposed that these cells may be transformed RPE, that they may arise from vitreal hyalocytes or be derived from perivascular adventitia. Alternatively they may come from a fibrocyte population as yet not identified in the retina. The behaviour of these

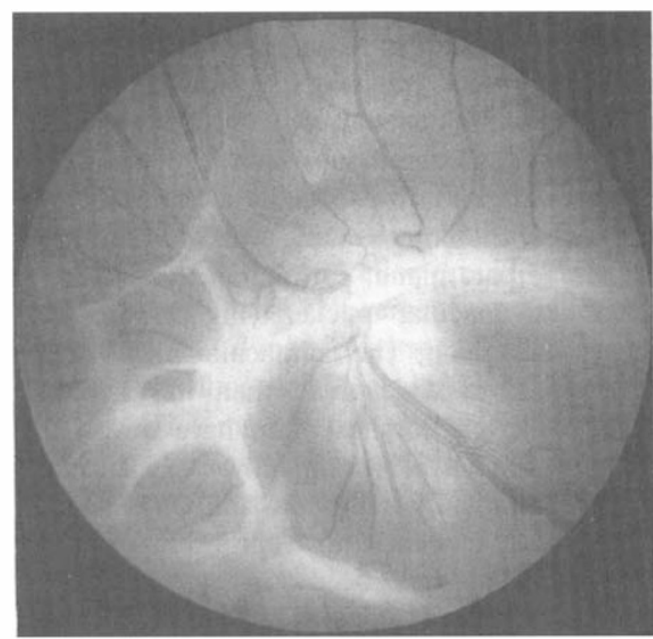

Fig. 3a. Fundus photograph of an ERM complicating pars planitis.

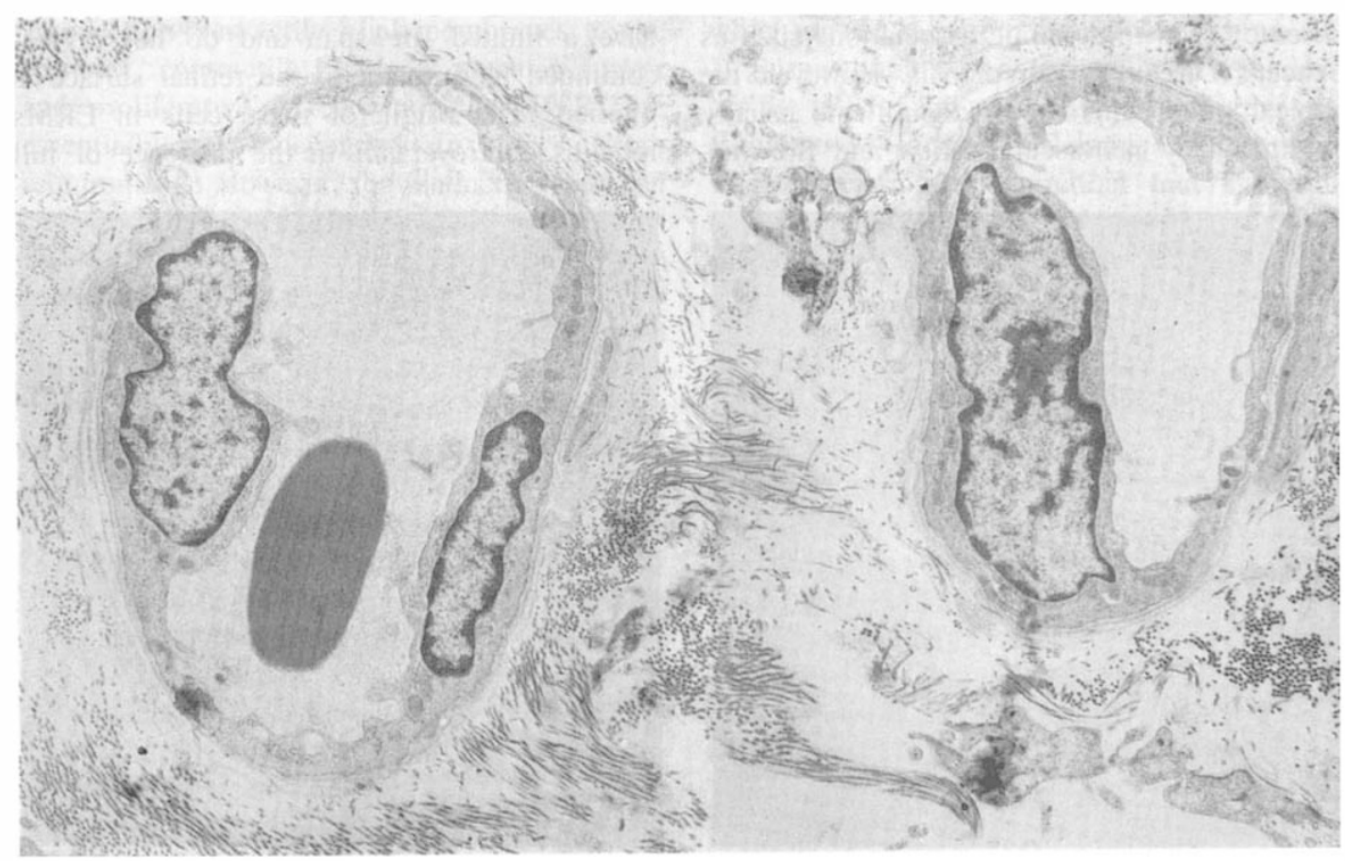

Fig. 3b. Transmission electron micrograph of the ERM in Figure 3 a demonstrating a vascular component. (Magnification $\times 4000$ ) 
cells in ERMs is probably as fibroblasts in healing wounds and elsewhere: i.e. they secrete a complex extracellular matrix comprising procollagen, glycosaminoglycans and $\mathrm{FN}$ and diminish in number as the membrane ages. Eventually they become entombed in mature, collagenous scar tissue.

FN is produced by activated macrophages ${ }^{36}$ as

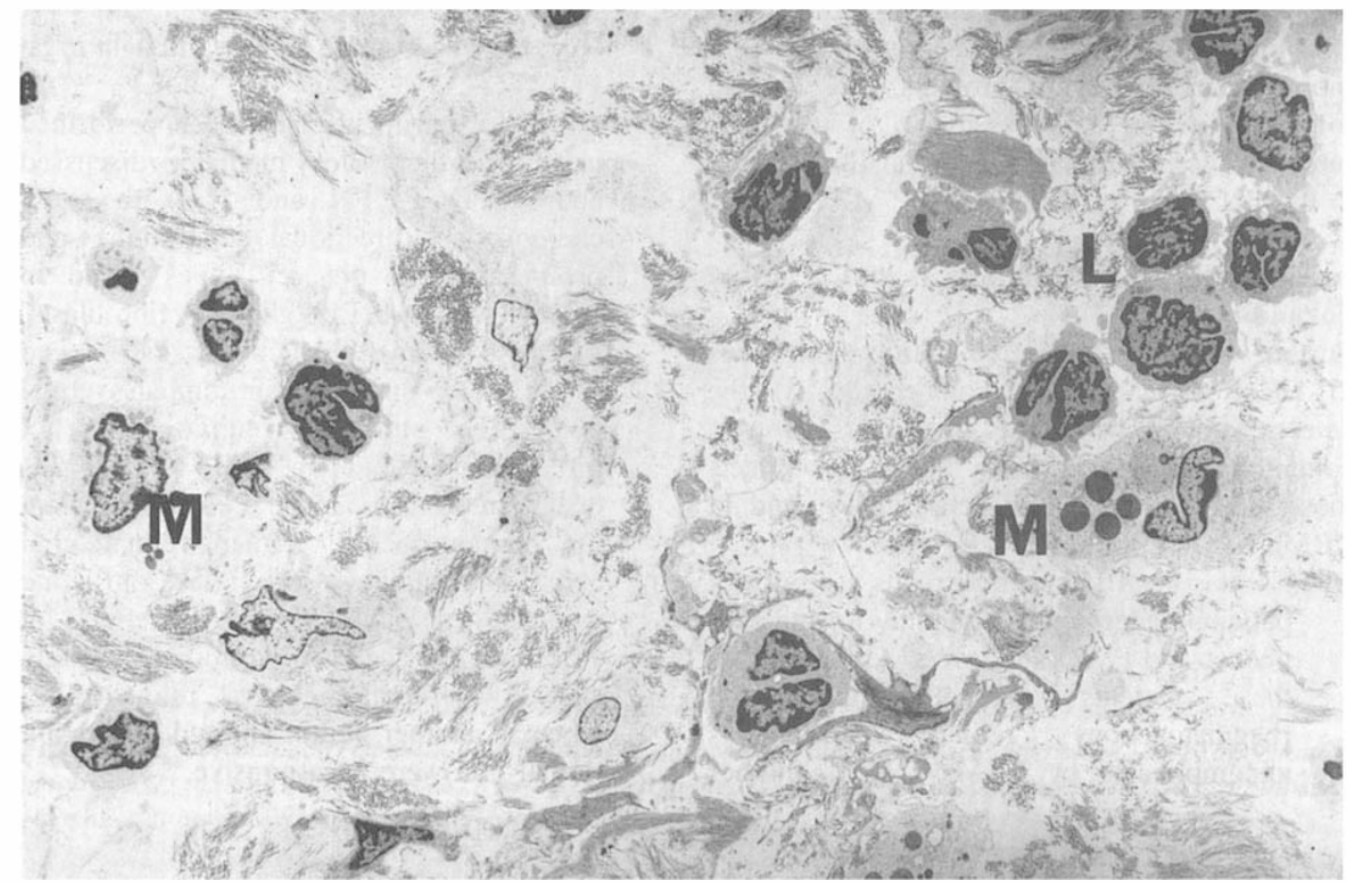

Fig. 3c. Macrophages $(M)$ and lymphocytes $(L)$ are abundant in the ERM shown in Figure 3a. (Magnification $\times 1500)$

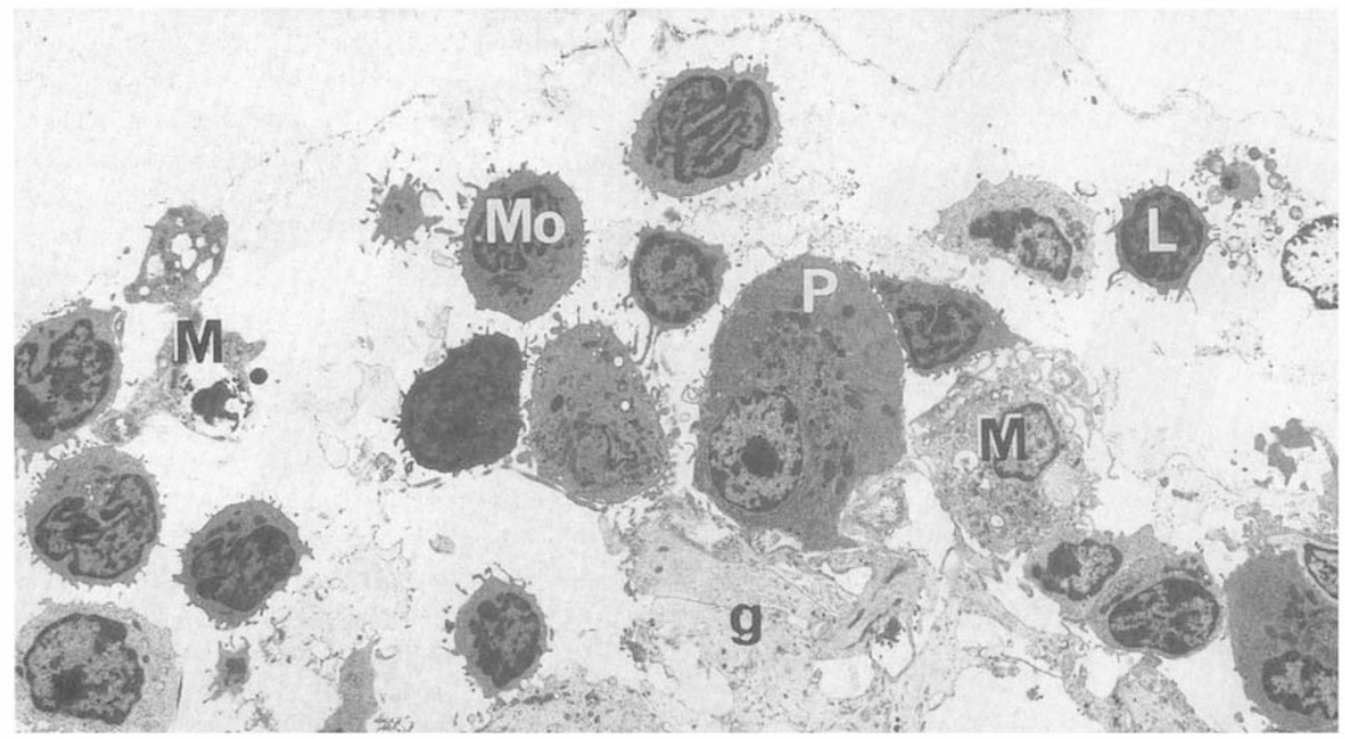

Fig. 4. Transmission electron micrograph of an epimacular membrane complicating pars planitis. Numerous inflammatory cells are present, including macrophages $(M)$, monocytes $(M o)$, lymphocytes $(L)$ and a plasma cell $(P)$. In addition, glial cell processes are also present $(g)$. (Magnification $\times 4000$ ) 
well as fibroblasts, glia and epithelial cells and it is therefore not surprising that it is found in abundance in early membranes as well as late membranes. ${ }^{7}$ This ubiquitous glycoprotein has many functions including cell-cell and cellsubstrate attachment, opsonisation and establishing transmembrane connections with intracellular contractile proteins. FN is also found in serum, and breakdown of the BRB secondary to inflammation could also contribute to the FN found in ERMs.

\section{Inflammatory Mediators and ERM} Formation:

Further evidence that inflammation contributes to ERM formation is provided by (i) the detection of inflammatory mediators in eyes containing ERMs and (ii) by the in vitro effects these substances have on cells types found in ERMs.

(i) FN has been found in vitreous aspirates of patients undergoing vitrectomy for macular pucker and PVR, and levels were higher in these patients than in those with rhegmatogenous retinal detachments uncomplicated by ERMs. ${ }^{37}$ IL-1, another macrophage derived mediator, has also been detected in $50 \%$ of subretinal and vitreous specimens from patients with complicated retinal detachment. ${ }^{38}$ Activated macrophages are also a potential source of PDGF $^{39}$ and vitreous from eyes with PVR contains a heat stable protein, thought to be PDGF. $^{40}$

(ii) In vitro experiments have been performed using the inflammatory mediators discussed above (PDGF, FN and IL-1) to study chemotaxis (directional migration) and proliferation of the cell types found in ERMs, namely RPE, glia and fibroblasts. FN is a chemoattractant for $\mathrm{RPE}^{40}$ and fibroblasts ${ }^{41}$ but not for human retinal glia. ${ }^{42}$ IL-1 stimulates migration but not proliferation of human RPE. ${ }^{43}$ PDGF has been demonstrated to be a chemoattractant for human RPE, ${ }^{44}$ human retinal glial cells ${ }^{42}$ and immature rat glia. ${ }^{45}$ Conflicting evidence exists concerning the effects of PDGF on glial cell proliferation: one study showed proliferation in rat retinal glia $^{44}$ whereas another author showed that rabbit retinal glia were unresponsive. ${ }^{46}$

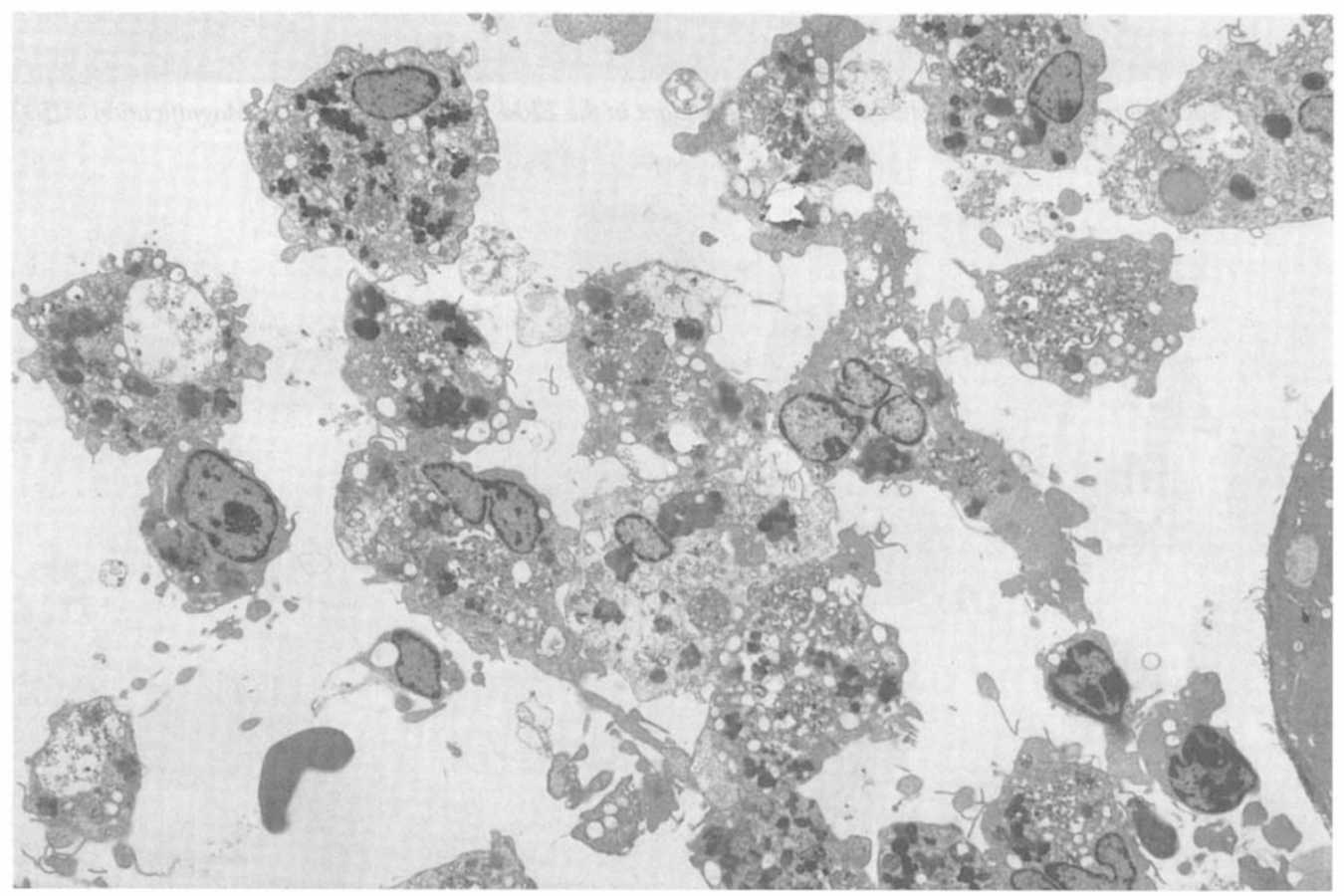

Fig. 5. Transmission electron micrograph of a bolus of macrophages 15 minutes after intravitreal injection. (Magnification $\times 2000)$ 


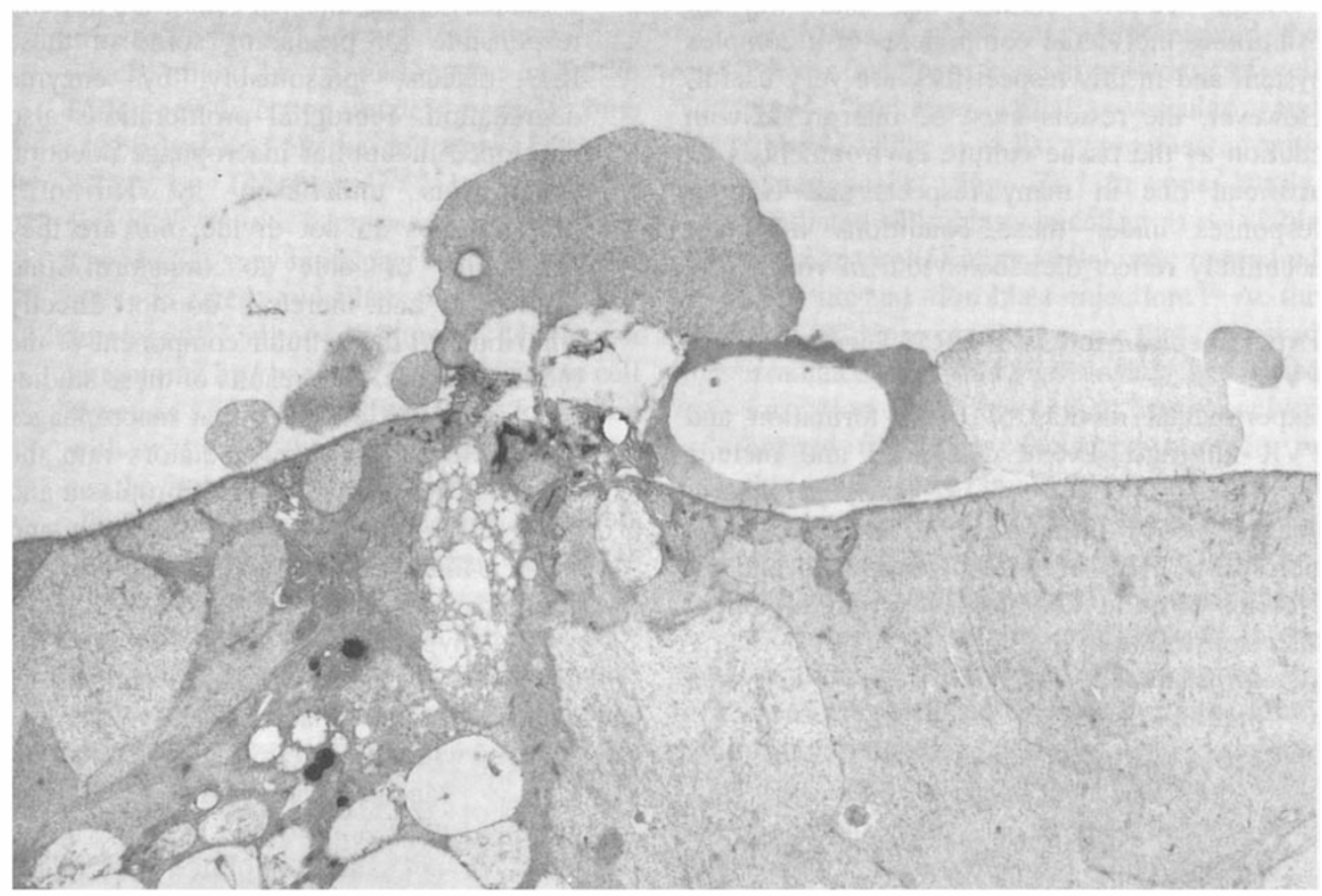

Fig. 6a. A transmission electron micrograph of the vitreoretinal interface one week after injection of macrophages into the rabbit vitreous. A defect is seen in the ILL through which neuroretinal tissue is prolapsing. (Magnification $\times 2000)$

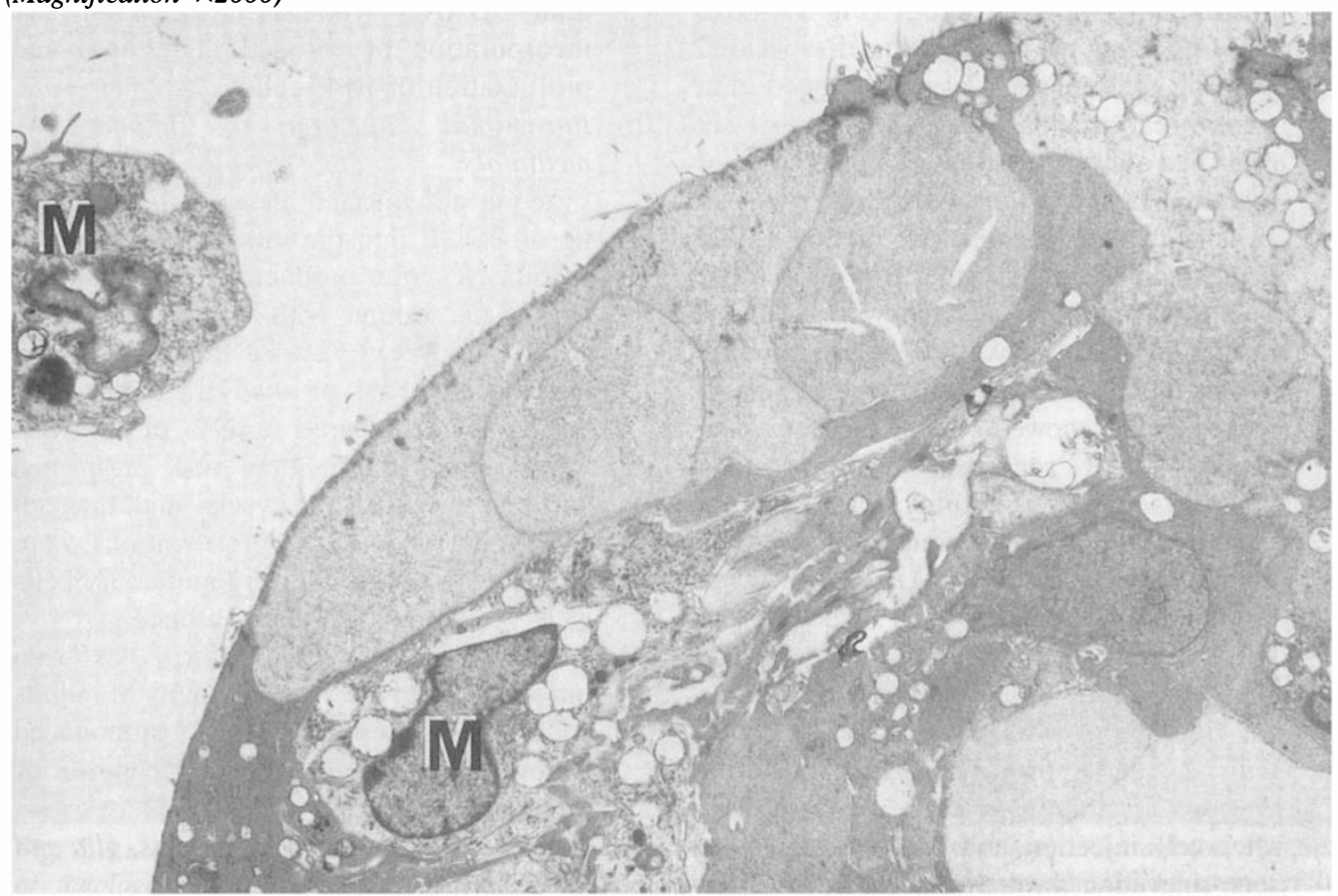

Fig. 6b. The ultrastructural appearance of an ERM eight weeks after macrophage injection into the rabbit vitreous. Macrophages (M) are present in the predominantly glial membrane. (Magnification $\times 4000)$ 
Tissue culture studies are one way of examining individual components of a complex system and in this respect they are very useful. However, the results must be interpreted with caution as the tissue culture environment is an artificial one in many respects and cellular responses under these conditions may not accurately reflect their behaviour in vivo.

\section{Experimental Models of ERM Formation and PVR:}

Experimental models of ERM formation and PVR fall into several categories and include intravitreal injection of (a) activated macrophages, (b) inflammatory mediators (c) fibroblasts, RPE or glia (d) endotoxin and (e) proteins (insulin and bovine serum albumen) after sensitisation.

\section{(a) Intravitreal injection of activated macrophages:}

In a pilot study undertaken by Grierson et al (unpublished data) 100,000 autologous activated peritoneal macrophages were injected into the vitreous cavity of seven rabbits. One animal was sacrificed after 15 minutes and histological examination confirmed the presence of a bolus of macrophages in the vitreous (Fig 5). Over the following days the bolus disappeared and all the injected eyes developed thin transvitreal strands. By four weeks all six eyes had developed dense, opaque vitreal membranes and by ten weeks four eyes had either localised or extensive traction retinal detachment secondary to ERM formation. The two remaining eyes showed no ERM formation after twelve weeks. Examination of the membranes at six, ten and twentyfour weeks showed the membranes to consist of senescent and young macrophages (presumably recruited from the uvea) and fibroblasts migrating from the region of the medullary ray. Glia were observed prolapsing through defects in the ILL and proliferating on the retinal surface (Figs 6a and b). This investigation supports the findings of a more extensive study by Hui et $a l ;{ }^{47}$ they observed posterior vitreous separation as early as eight days after cell injection and Müller cells were seen migrating through defects in the ILL. These authors provided compelling pictorial evidence that the injected cells were directly responsible for producing some of these ILL defects, presumably by enzyme degradation. Fibroglial proliferations also developed in similiar macrophage injection experiments undertaken by Kirrhof. ${ }^{48}$ Macrophages do not divide, nor are they contractile or able to transform into fibroblasts and therefore do not directly contribute to the cellular component of the induced ERMs. The results of these studies provide cogent evidence that macrophages synthesise and release mediators into the vitreous cavity which evoke fibroplasia and glial cell migration and proliferation and that it is these recruited cells which form the complex, contractile ERMs seen.

This hypothesis is supported by the results of tissue culture experiments in which vitreous macrophages were cocultured with rabbit retinal glia ${ }^{49}$ and rabbit RPE. ${ }^{50}$ Macrophage invasion of the vitreous was stimulated by intravitreal injection of haemoglobin ${ }^{49}$ or latex spheres $^{50}$ a few days before the vitreous was removed. Co-culturing the macrophages with glial cells resulted in increased glial DNA synthesis (measured by incorporation of tritiated thymidine) and proliferation of RPE cells.

(b) Intravitreal injection of inflammatory mediators:

Yeo et $\mathrm{al}^{51}$ injected $50 \mu \mathrm{g}$ of $\mathrm{FN}$ and 100 ng of PDGF into the vitreous cavity of 18 rabbits eyes after producing a full thickness pars plana wound with vitreous prolapse. After four weeks $72 \%$ of treated eyes had developed partial or total traction retinal detachment compared to $19 \%$ of controls. Histological examination was performed between two and six weeks and the cell types observed in the proliferations were glia and fibroblasts, but inflammatory cells were remarkable by their absence.

IL-1 in a slow release form has been introduced into the vitreous cavity of rabbits and this resulted in pronounced fibrovascular proliferation in the posterior segment. 52

(c) Intravitreal injection of fibroblasts, glia and RPE:

In order to study the natural history and 
pathogenesis of ERM formation and to investigate the efficacy and toxicity of drugs which might be of therapeutic value in PVR, cell injection models have become established and all the cell types found in ERMs i.e. fibroblasts, ${ }^{53-63}$ RPE cells ${ }^{64-66}$ and glia ${ }^{67,68}$ have been used in this model. The studies vary in respect to the number of cells injected, whether homologous or autologous cells were used, whether a vitrectomy had been performed prior to cell injection and cell viability. ERM formation with or without traction retinal detachment can be induced by intravitreal injection of all of these cell types and the critical factors which determine the extent of ERM formation are the number of cells injected, ${ }^{56}$ the state of the vitreous gel ${ }^{60}$ and whether autologous or homologous cells are used. ${ }^{59}$ Other interesting findings which emerge from these studies are that, regardless of which cell type is injected, the ERMs that form contain a variety of cell types including glial, vascular and fibroblast-like cells together with macrophages (Fig 7). In one study, irradiated fibroblast injection (i.e. viable but non-proliferating cells) was compared with normal fibroblast injection. ${ }^{57}$ At the end of four weeks, eyes that received irradiated cells had significantly less ERM formation than eyes that had received normal fibroblasts. However, numbers in this study were small (six eyes) and the follow up short (four weeks). This experiment has been repeated by another group $^{62}$ who made a quantitative assessment of cellular proliferation in the vitreous, retina and optic nerve by measuring tritiated thymidine uptake. They

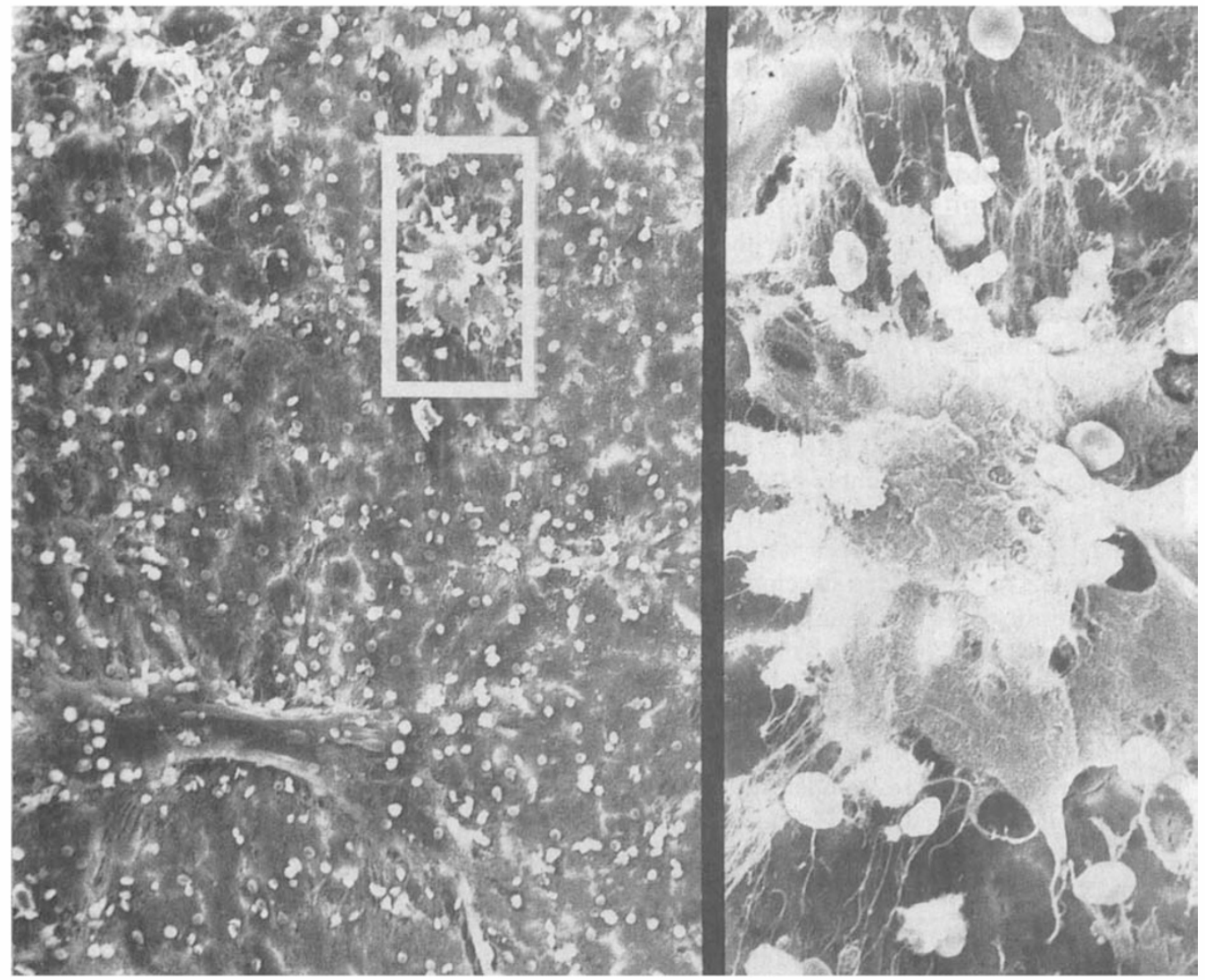

Fig. 7. A scanning electron micrograph of the retinal surface of the rabbit two months after intravitreal injection of autologous fibroblasts, showing an ERM comprising glial cells and numerous inflammatory cells. (Magnification $\times 150$; inset $\times 750$ ) 
showed no significant difference between the two groups. Fibroblasts have also been disrupted by repeat freeze-thawing and the resulting cell debris injected;63 at four weeks there was no significant difference between the cell debris group and the whole, viable cell group with respect to inflammatory signs and the incidence of traction retinal detachment, $(86 \%$ vs $100 \%)$. Pre-labelling the injected cells with tritiated thymidine allows their subsequent detection autoradiographically. Using this technique it was clearly demonstrated that proliferating host cells around the optic nerve head, rather than proliferating injected cells, contributed significantly to the induced ERMs. This was particularly true if homologous rather than autologous cells were used. If autologous cells are injected they are found in higher numbers in the ERMS, which develop more slowly. This apparently disparate information can be reconciled: up to $20 \%$ of injected fibroblasts die within 24 hours of injection into the vitreous cavity ${ }^{31}$ and this is presumably true whether the cells are fibroblasts, RPE, irradiated or viable cells. The resulting cell debris is thought to stimulate the inflammatory reaction reported by some authors, which develops within a few days of cell injection. This would explain, in part at least, why injection of larger cell numbers results in more pronounced ERM formation; conversely a larger number of cells remain viable and able to proliferate. In a further study formalin-killed cells were injected ${ }^{57}$ and none of these eyes developed ERMs. This result could be explained by the fact that formalin is a protein fixative; "fixed" cells would not stimulate such a vigorous inflammatory reaction as the proteins and enzymes released by dying cells.

There is therefore compelling evidence that cell death in the injection models of PVR stimulates an inflammatory reaction and that the cellular and chemically mediated consequences of the inflammatory response lead to migration and proliferation of host cells and that the ERMs which develop do so as part of a wound healing process. (d) Intravitreal injection of endotoxin:

Intraocular injection of endotoxin has been used as a model of anterior uveitis ${ }^{2}$ and has also been employed intravitreally to stimulate a vigorous inflammatory response in the posterior segment. ${ }^{69}$ Early exudative retinal detachments developed and subsequently glial cells appeared to erupt through intact ILL (Fig 8a). As the acute inflammatory reaction subsided mainly glial ERMs developed, but numerous fibroblast-like cells and macrophages were also present (Fig $8 \mathrm{~b}$ ). It seems likely that the intravitreal endotoxin led to the release of complement derived or other leucocyte migration factors which recruited the component cells found in these ERMs

(e) Antigenic stimulation of inflammation:

If an animal is sensitised to a protein by repeated intradermal low dose injection of a protein combined with Freunds adjuvant, subsequent challenge with the protein results in an exaggerated immunogenic

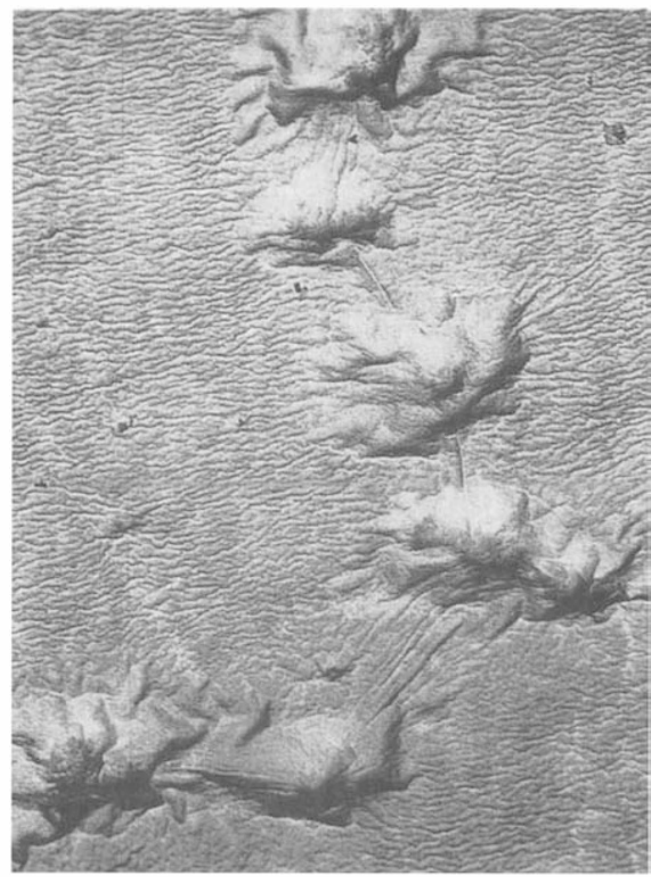

Fig. 8a. A scanning electron micrograph of the retinal surface five weeks after injection of Shigella endotoxin into the rabbit vitreous. The ILL exhibits elevations and radiating folds produced by retinal glial cells, which subsequently migrated onto the retinal surface through ILL defects. (Magnification $\times 1500$ ) 
inflamatory response (Arthus reaction) ${ }^{4}$. This procedure has been followed in Rhesus monkeys using insulin and bovine serum albumen with intravitreal injection following sensitisation. ${ }^{70,71}$ In both models a marked retinal vasculopathy developed which was followed by the development of fibrovascular epiretinal proliferation.

\section{Anti-Inflammatory Agents in Experimental Models of PVR}

Cell injection and trauma models of ERM formation and PVR have been used to study the effects of a range of drugs on the development of contractile ERMs. Steroids (Dexamethasone and Triamcinolone Acetonamide) have been studied because of their known inhibitory effect on fibroblast proliferation ${ }^{72}$ and as they have been used intraocularly without side effects. ${ }^{73}$ In the initial investigation, ${ }^{74} \mathrm{lmg}$ of dexamethasone alcohol suspension was injected intravitreally immediately following intravitreal injection of 250,000 dermal fibroblasts. On the first postoperative day the treatment group had significantly less cellular debris and inflammatory cells in the inferior vitreous cavity than controls, and by 28 days $57 \%$ of controls had traction retinal detachment compared to $24 \%$ of treated eyes. Neovascularisation associated with membrane formation was also significantly reduced from $19 \%$ to $4 \%$. In a further study, the more potent steroid triamcinolone acetonamide was used. ${ }^{75}$ The same number of dermal fibroblasts were injected and once again the treatment group had significantly less traction retinal detachment and neovascularisation than the untreated eyes. In another experiment 25,000 dermal fibroblasts were injected into eyes that had previously undergone gas-compression vitrectomy, which more closely mimics the human situation in which PVR develops. ${ }^{76}$ Under these circumstances the results were less striking; traction retinal detachment developed in $56 \%$ of treated eyes compared to $90 \%$ of controls. Possible explanations for these results could be that in the vitrectomy model injected cells have readier access to the retinal surface where they can proliferate, or injected steroid may not persist for long enough at therapeutic levels in the vitrectomised eye. However, if the steroid is injected 24 or 48 hours prior to cell injection there is a further reduction of detach-

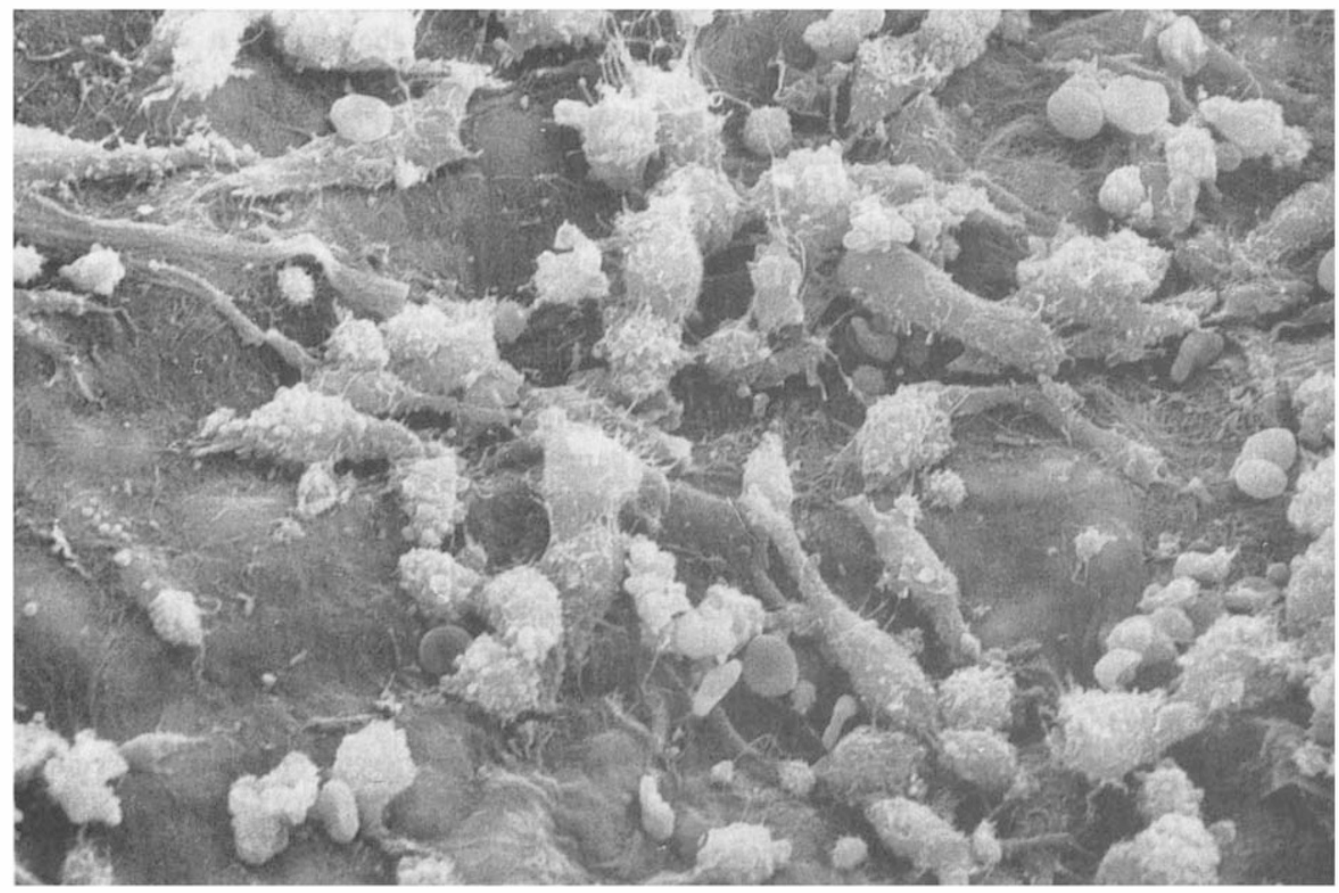

Fig. 8b. Scanning electron micrograph of an endotoxin-induced ERM in a rabbit eye. Many inflammatory cells are present on the surface of the membrane. (Magnification $\times 1000$ ) 
ment in the treated group. ${ }^{77,62}$ If high doses of systemic steroids are administered 24 hours before injection of irradiated fibroblasts in addition to intravitreal steroids, traction retinal detachment is virtually abolished. ${ }^{78}$ Other investigators have confirmed these findings in cell injection models ${ }^{79}$ and after penetrating injury in rabbits. ${ }^{80}$ However, if dense vitreous haemorrhage was induced at the time of surgical injury no beneficial effects from steroids were observed. ${ }^{81}$ The group in the latter study were, however, very small and clinical assessment of membrane formation difficult due to the presence of intravitreal blood.

The mechanisms by which steroids delay wound healing are highly complex; they not only have multiple effects on the immune and vascular systems but are also potent antiinflammatory agents and inhibitors of cell proliferation. Dexamethasone has been shown to inhibit proliferation of RPE, Tenons fibroblasts and vascular endothelial cells in vitro ${ }^{82}$ and paradoxically stimulates proliferation of dermal fibroblasts at high concentrations. ${ }^{83}$ In cell injection models, steroids may therefore reduce the incidence of ERM formation by a direct effect on the injected cells. The facts that pretreatment, the addition of systemic steroids and reduction of membranes in the model where irradiated, non-proliferating cells were used suggests that this is not the only mechanism. Systemic steroids reduce the number of circulating monocytes and this reduces the number of macrophages recruited to sites of inflammation. ${ }^{84}$ In addition, pre-treatment with steroids promotes synthesis of regulatory proteins, such as lipocortins (which inhibit phospholipase release of arachnidonic acid), angiotensin converting enzyme (which regulates vascular tone and permeability) and "vasocortin" (which modulates vascular permeability). (Cited by Chandler) ${ }^{77}$. Pre-treatment therefore primes the tissues prior to the stimulating insult and a more immediate antiinflammatory response occurs. A significant part of the effectiveness of steroids in reducing ERMs in cell injection models of PVR is therefore almost certainly due to their antiinflammatory action.

Systemic steroids have been used in a controlled clinical trial of 126 patients undergoing surgery for retinal detachment. ${ }^{85}$
The degree of ERM formation was graded preand postoperatively and patients randomly allocated to steroid or placebo. The treatment group received $100 \mathrm{mg}$ Prednisolone daily for five days starting on the fifth post-operative day with reducing doses thereafter for 40 days. Results at 27 weeks showed some reduction in post-operative ERM formation in treated patients who showed minimal ERM formation pre-operatively, but otherwise no significant difference was noted. This regime may have been ineffective in preventing ERM formation as intraocular levels of steroid may not have been sufficiently high and treatment was started on the fifth post-operative day by which time surgically induced inflammation would have been well established.

Surgical trauma has been shown to break down the BRB (investigated using vitreous fluorophotometry $)^{86}$ while cyrothermy as well as causing mechanical trauma, is associated with a local inflammatory response. ${ }^{87}$ In a study comparing the effectiveness of systemic pretreatment with Dexamethasone or Indomethacin (an inhibitor of prostaglandin synthesis) on BRB breakdown following cryothermy, both drugs were found to be effective, although fluoroscein leakage was not abolished. ${ }^{88}$ It was suggested that under these circumstances the drugs were ineffective at reducing BRB breakdown caused by mechanical trauma but that subsequent exacerbation mediated by inflammatory processes was attenuated. In the clinical setting prostaglandin inhibitors are regularly used by some surgeons following vitreoretinal surgery (McLeod, personal communication).

\section{Conclusion:}

There is compelling clinical, histological and experimental evidence that inflammation plays an important role in the pathogenesis of ERM formation and that the development of contractile membranes can be likened to the healing phase of the inflammatory response.

Macrophages, which have consistently been reported in histological studies, play a central role, orchestrating events and modifying cellular behaviour via inflammatory mediators. Some of these compounds have been found in vitreous and subretinal fluid samples from eyes containing ERMs and in vitro experiments have demonstrated that these substances modulate the 
behaviour of the cells types found in ERMs. ERMs can be induced in experimental animals by intravitreal injection of substances that stimulate an inflammatory reaction, or by the injection of inflammatory mediators themselves. In cell injection models of PVR the evidence suggests that death of the injected cells stimulates an inflammatory response and that this plays a crucial part in subsequent cellular events. The beneficial effects of steroid treatment in these models underlines the importance of inflammatory processes. The vitreous also plays an important part in ERM formation, not only by providing a scaffold for cell growth but also by its modulating effects on cell behaviour. However, experimental models differ in many respects from the clinical setting in which contractile ERMs arise. It is important to distinguish cause from effect but the evidence suggests that inflammatory processes are causative in ERM formation rather than a secondary phenomenon.

This work has been supported by the T.F.C. Frost Charitable Trust and the Wellcome Trust (Grant no. 17095/1.4R).

\section{References}

' Opie EL. Cited by Forbus WD in Granulomatous Inflammation. Springfield, Ill, Charles C Thomas 1949 p 5.

2 Rosenbaum JT and Raymond W. Monocyte chemotactic activity induced by intravitreal endotoxin. Invest Ophthalmol Vis Sci 1985; 26: 1267-73.

3 Adams DO and Turner SR. Acute inflammation. Marcel Dekker ed. Garner A, Gordon K. Clintworth 1982: 59-89.

${ }^{4}$ Woolfe N. Cell, tissue and disease. The basis of pathology. Second ed. Bailliere Tindall 1986, p 31-166.

5 Diegelman RF, Cohen IK, Caplan AM. The role of macrophages in wound repair; a review. Plastic and Reconstr Surg 1981; 68: 107-13.

${ }^{6}$ Grierson I, Joseph J, Miller M, Day JE. Wound repair: the fibroblast and inhibition of scar formation. Eye 1988; 2: 135-48.

${ }^{7}$ Hiscott PS, Grierson I, McLeod D. Natural history of fibrocellular epiretinal membranes: a quantitative, autoradiographic and immunohistochemical study. Br J Ophthalmol 1985; 69: 810-23.

${ }^{8}$ Grabner G, Boltz G, Forster O. Macrophage-like properties of human hyalocytes. Invest Ophthalmol Vis Sci 1980; 19: 333-40.
${ }^{9}$ Martini BT, Sorgente N, Frauchiger W, Ryan SJ. Vitreous modulation of human retinal pigment epithelium in vitro. Invest Ophthalmol Vis Sci 1988 suppl; 29: 91.

${ }^{10}$ Raymond L and Jacobson B. Isolation and identification of stimulatory and inhibitory growth factors in bovine vitreous. Exp Eye Res 1982; 34: 267-86.

"McLeod D, Hiscott PS, Grierson I. Age-related proliferation at the vitreoretinal juncture. Eye 1987; 1: 263-81.

${ }^{1}$ Hiscott PS, Grierson I, Trombetta CJ, Rahi AHS, Marshall J, McLeod D. Retinal and epiretinal glia - an immunohistochemical study. $B r \quad J$ Ophthalmol 1984; 68: 698-707.

${ }^{13}$ Machemer $\mathrm{R}$ and Laqua $\mathrm{H}$. Pigment epithelium proliferation in retinal detachment (massive preretinal proliferation). Am J Ophthalmol 1975; 80: $1-23$.

${ }^{14}$ Campochiaro PA, Bryan JA, Conway BP, Jaccoma EH. Intravitreal chemotactic and mitogenic activity. Implications of blood-retinal barrier breakdown. Arch Ophthalmol 1986; 104: 1685-7.

${ }^{15}$ Harvey AK, Roberge F, Hjelmeland L. Chemotaxis of rat retinal glia to growth factors found in repairing wounds. Invest Ophthalmol Vis Sci 1987; 28: 1092-9.

${ }^{16}$ McLeod D, Marshall J, Grierson I. Epimacular membrane peeling. Trans Ophthalmol Soc UK 1981; 101: 170-80.

${ }^{17}$ Foos RY. Non-vascularised proliferative extraretinal retinopathy. Am J Ophthalmol 1978; 86: 723-5.

${ }^{18}$ Graham E, Stanford M, Scilling JS, Sanders M. Neovascularisation associated with posterior uveitis. Br J Ophthalmol 1987; 71: 826-33.

${ }^{19}$ Clarkson JG, Green WR, Massof DA. Histopathic review of 168 cases of preretinal membrane. Am J Ophthalmol 1977; 84: 1-17.

${ }^{20}$ Bonnet $\mathrm{M}$. Clinical factors predisposing to massive proliferative vitreoretinopathy in rhegmatogenous retinal detachment. Ophthalmologica (Basel). 1984; 188: 148-52.

${ }^{21}$ Chignell AH, Clemett RS, Revi IHS. Pigment fallout and uveitis after cryothermy. $\mathrm{Br} J$ Ophthalmol 1973; 57: 156-65.

22 Lewis $\mathrm{H}$ and Aaberg TM. Anterior proliferative vitreoretinopathy. Am J Ophthalmol 1988; 105: $277-84$.

${ }_{23}^{23}$ Nussenblatt RB. Macular alterations secondary to intraocular inflammatory disease. Ophthalmology 1986; 93: 984-8.

${ }^{24}$ Baines PS, Hiscott PS, McLeod D. Posterior nonvascularised proliferative extraretinopathy and peripheral nodular retinal telangiectasis. Trans Ophthalmol Soc UK 1982; 102: 491-7.

${ }^{25}$ Grierson I, Hiscott PS, Hitchins CA, McKechnie 
NM, White V, McLeod D. Which cells are involved in the formation of epiretinal membranes? Seminars in Ophthalmology 1987; 2: 99-109.

${ }^{26}$ Kenyon KR and Michels RG. Ultrastructure of epiretinal membrane removed by pars plana vitreoretinal surgery. Am J Ophthalmol 1977; 83: 815-23.

${ }^{27}$ Kampik A, Kenyon KR, Michels RG. Epiretinal and vitreous membranes. Arch Ophthalmol 1981; 99: $1445-54$.

${ }^{28}$ Trese M, Chandler DB, Machemer R. Macular pucker II ultrastructure. Graefes Arch Clin Exp Ophthalmol 1983; 221: 16-26.

29 Johnson NE and Foulds WS. Observations on the retinal pigment epithelium and retinal macrophages in experimental retinal detachment. Br J Ophthalmol 1977; 61: 567-72.

${ }^{30}$ Personal communication Forrester J.

${ }^{31}$ Grierson I and Forrester JV. Vitreous haemorrhage and vitreal membranes. Trans Ophthalmol Soc UK 1980; 100: 140-50.

${ }^{32}$ Cleary PE and Ryan SJ. Histology of wound, vitreous retina in experimental posterior penetrating eye injury in the Rhesus monkey. $\mathrm{Am}$ J Ophthalmol 1979; 88: 221-31.

${ }^{33}$ Trese MT, Chandler DB, Machemer R. Subretinal strands: ultrastructural features. Graefes Arch Clin Exp Ophthalmol 1985; 223: 35-40.

${ }^{34}$ Newsome DA, Rodrigues MM, Machemer R. Human massive periretinal proliferation. In vitro characteristics of cellular components. Arch Ophthalmol 1981; 99: 873-80.

${ }^{35}$ Hiscott PS, Grierson I, Hitchins CA, Rahi AHS, McLeod D. Experimental membranes in vitro. Trans Ophthalmol Soc UK 1983; 103: 89-102.

${ }^{36}$ Tsukamoto Y, Helsel WE, Wahl L. Macrophage production of fibronectin, a chemoattractant for fibroblasts. J Immunol 1981; 127: 673-8.

${ }^{37}$ Campochiaro PA, Jerdan JA, Glaser BM, Cardin A, Michels RG. Vitreous aspirates from patients with vitreoretinopathy stimulate retinal pigment epithelial cell migration. Arch Ophthalmol 1985; 103: $1402-5$.

${ }^{38}$ Davis JL, Jalk AE, Roberge F, Caspi R, Fujun HW, Schepens CL, Nussenblatt RB. Subretinal fluid from human retinal detachment contains interleukin-1. Invest Ophthalmol Vis Sci 1988 Suppl; 29: 396.

${ }^{39}$ Shimokado K, Ranes EW, Nadtes DKM, Barrett TB, Benditt EP, Ross RA. A significant part of macrophage-derived growth factor consists of at least two forms of PDGF. Cell 1985; 43: 277-86.

${ }^{40}$ Campochiaro PA, Jerdan JA, Glaser BM. Serum contains chemoattractants for human retinal pigment epithelium cells. Arch Ophthalmol 1984; 102: 1830-3.
${ }^{41}$ Postlethwaite AE, Keski-Oja J, Bahan G. et al. Induction of fibroblast chemotaxis by fibronectin. J Exp Med 1981; 153: 494-9.

${ }^{42}$ Hjelmeland LM, Harvey AK, Hohman TC, de Juan E. Primary culture and chemotactic responses of human glia. Invest Ophthalmol Vis Sci 1987 Suppl; 28: 208.

${ }^{43}$ Kirhhof B, Kirhhof E, Sorgente N, Ryan SJ. Interleukin-1 stimulates migration but not proliferation of pigment epithelial cells in vitro. Invest Ophthalmol Vis Sci 1987 Suppl; 28: 208.

${ }^{44}$ Campochiaro PA and Glaser BM. Platelet derived growth factor is chemotactic for human pigment epithelial cells. Arch Ophthalmol 1985; 103: 576-9.

${ }^{45}$ Dickson J, de Juan E, Hjelmeland LM. Retinal glial cells respond to serum. Invest Ophthalmol Vis Sci 1987 Suppl; 28: 208.

${ }^{46}$ Burke J. Cultured retinal glial cells are insensitive to platelet-derived growth factor. Exp Eye Res 1982; 5: 663-9.

${ }^{47}$ Hui YN, Sorgente N, Ryan SJ. Posterior segment separation and retinal detachment induced by macrophages. Graefes Arch Clin Exp Ophthalmol 1987; 225: 279-84.

${ }^{48}$ Kirhhof B, Kirhhof E, Ryan SJ, Dixon JP, Barton $\mathrm{BE}$, Sorgente N. Macrophage modulation of retinal pigment epithelial cell migration and proliferation. Graefes Arch Clin Exp Ophthalmol 1988; (In Press).

${ }^{49}$ Burke JM. Phagocytes that invade the vitreous after injury stimulate DNA synthesis in neural retina in vitro. Graefes Arch Clin Exp Ophthalmol 1980; 214: 223-7.

${ }^{50}$ Burke JM and Twinning SS. Vitreous macrophage elicitation: generation of stimulants for pigment epithelium in vitro. Invest Ophthalmol Vis Sci 1987; 28: 1100-7.

${ }^{51}$ Yeo JH, Sadeghi J, Campochiaro PA, Green WR, Glaser BM. Intravitreous fibronectin and platelet-derived growth factor. New model for traction retinal detachment. Arch Ophthalmol 1986; 104: 417-21.

${ }^{52} \mathrm{Hemo} \mathrm{H}$ and BenEzra D. The role of interleukins in neovascularisation. Invest Ophthalmol Vis Sci 1987 Suppl; 28: 320.

${ }^{53}$ Algvere $\mathrm{P}$ and Koch E. Experimental fibroplasia in the rabbit vitreous. Retinal detachment induced by autologous fibroblasts. Graefes Arch Clin Exp Ophthalmol 1976; 199: 215-22.

${ }^{54}$ Sugita G, Tano Y, Machemer R, Abrams G, Claflin A, Fiorentino G. Intravitreal transplantation of fibroblasts. Am J Ophthalmol 1980; 89: $121-30$.

${ }^{55}$ Grierson I and Rahi AHS. Structural basis of contraction in vitreal fibrous membranes. $\mathrm{Br} J$ Ophthalmol 1981; 61: 737-49. 
${ }^{56}$ Fastenberg DM, Diddie KR, Sorgente N, Ryan SJ. A comparison of different cellular inocula in an experimental model of massive preretinal proliferation. Am J Ophthalmol 1982; 93: 559-64.

${ }^{57}$ Fastenberg DM, Diddie KR, Dorey K, Ryan SJ. The role of cellular proliferation in an experimental model of massive periretinal proliferation. Am J Ophthalmol 1982; 93: 565-72.

${ }^{58}$ Hsu H-T, Dorey K, Sorgente N, Ryan SJ. Surgical removal of the vitreous. Its effects on intraocular fibroblast proliferation in the rabbit. Arch Ophthalmol 1984; 102: 605-7.

${ }^{59}$ Hitchins CA, Grierson I, Hiscott PS. The effects of injections of cultured fibroblasts into the rabbit vitreous. Graefes Arch Clin Exp Ophthalmol 1985; 223: 237-49.

${ }^{60}$ Chandler DB, Quansah FA, Hida T, Machemer R. A refined experimental model of proliferative vitreoretinopathy. Graefes Arch Clin Exp Ophthalmol 1986; 224: 860.

${ }^{61}$ Algvere $\mathrm{P}$ and Landan IM. Implantation of fibroblasts into vitrectomised eyes. Ophthalmic Res 1987; 19: 271-6.

62 Hatchell D, McAdoo T, Sheta S, King RT, Bartololme JV. Quantification of cellular proliferation in experimental proliferative vitreoretinopathy. Arch Ophthalmol 1988; 106: 669-72.

6 . Hitchins CA. PhD thesis, London, 1986.

${ }^{64}$ Mandlecorn MS, Machemer R, Fineberg E, Hersch SB. Proliferation and metaplasia of intravitreal retinal pigment epithelial cell autotransplants. Am J Ophthalmol 1975; 80: 227-37.

${ }^{65}$ Muller-Jensen K, Machemer R, Azarina R. Autotransplantation of retinal pigment epithelium in intravitreal diffusion chamber. Am J Ophthalmol 1975; : 80: 530-7.

${ }^{66}$ Radtke ND, Tano Y, Chandler DB, Machemer R. Stimulation of massive periretinal proliferation by autotransplantation of retinal pigment epithelial cells. Am J Ophthalmol 1981; 91: 76-87.

${ }^{67}$ Peters MA, Burke JM, Clowry M, Abrams GW, Williams GA. Development of traction retinal detachment following intravitreal injections of Muller and pigment epithelial cells. Graefes Arch Clin Exp Ophthalmol 1986; 224: 554-63.

${ }^{68} \mathrm{Wu} \mathrm{C}$ and Huang DSS. Experimental PVR model with autotransplantation of glial cells and fibroblasts. Invest Ophthalmol Vis Sci 1988 Suppl; 29: 306.

${ }^{69}$ Hiscott PS, Grierson I, Unger W, Hitchins CA. Endotoxine intravitriere: un Modele pour la production des membranes epiretiniennes chez le lapin. J Fr Ophtalmol 1984; 7: 660.

${ }^{70}$ Shabo AL and Maxwell DS. Insulin-induced immunogenic retinopathy resembling the retinitis proliferans of diabetes. Trans Acad Ophthalmol Otol 1976; 81: 497-508.
7) Shabo AL and Maxwell DS. Experimental immunogenic proliferative retinpathy in monkeys. Am J Ophthalmol 1977; 83: 471-80.

${ }^{72}$ Ruhmann AG and Berliner DI. Influence of steroids on fibroblasts. II The fibroblast as an assay system for topical anti-inflammatory potency of corticosteroids. J Invest Dermatol 1967; 49: 123-30.

${ }^{73}$ Graham RO and Peyman GA. Intravitreal injection of dexamethasone. Arch Ophthalmol 1974; 92: 149-54.

${ }^{74}$ Tano Y, Sugita G, Abrams G, Machemer R. Inhibition of intraocular proliferations with intravitreal corticosteroids. Am J Ophthalmol 1980; 89: 131-6.

75 Tano Y, Chandler DB, Machemer R. Treatment of intraocular proliferation with intravitreal injection of triamcinolone acetonide. $A m \quad J$ Ophthalmol 1980; 90: 810-16.

${ }^{76}$ Chandler DB, Rozakis G, de Juan E, Machemer R. The effect of triamcinolone acetonide on a refined experimental model of proliferative retinopathy. Am J Ophthalmol 1985; 99: 686-90.

${ }^{77}$ Chandler DB, Hida T, Sheta S, Proia AD, Machemer R. Improvement in efficiency of corticosteroid therapy in an animal model of proliferative vitreoretinopathy by pretreatment. Graefes Arch Clin Exp Ophthalmol 1987; 225: 259-65.

${ }^{78}$ Chandler DB, Hida T, Rozakis G, Machemer R. The effects of steroids on cell contraction in experimental proliferative vitreoretinopathy. Invest Ophthalmol Vis Sci 1988 Suppl; 29: 207.

${ }^{79}$ Sunlap M, Wiedmann P, Sorgente N, Ryan SJ. Effects of cytotoxin drugs on proliferative vitreoretinopathy in the rabbit cell injection model. Curr Eye Res 1984; 3: 619-23.

${ }^{80}$ Tano Y, Chandler DB, McCuen BW, Machemer R. Glucocorticoid inhibition of intraocular proliferation after injury. Am J Ophthalmol 1981; 91: 184-9.

${ }^{81}$ Meyers SM and Rodrigues MM. Effect of selected intravitreal drugs after severe penetrating injury in rabbits. Curr Eye Res 1981; 1: 471-7.

82 Boulton M, Singh A, Wong HC, McLeod D. Dexamethasone therapy directly and indirectly inhibits the proliferation of retinal microvascular endothelial cells. Invest Ophthalmol Vis Sci 1988 Suppl; 29: 243.

${ }^{83}$ Blumenkranz MS, Claflin A, Hajek AS. Selection of therapeutic agents for intraocular proliferative disease. Cell culture evaluation. Arch Ophthalmol 1984; 102: 598-604.

${ }^{84}$ Leibovich SJ and Ross R. The role of the macrophage in wound repair. A study with hydrocortisone and anti-macrophage serum. Am J Pathol; 78: 71-90. 
${ }^{85}$ Koerner F, Mertz A, Gloor B, Wagner E. Postoperative retinal fibrosis - a controlled clinical study of systemic steroid therapy. Graefes Arch Clin Exp Ophthalmol 1982; 219: 268-71.

${ }^{86}$ Campochiaro PA and Conway P. Quantitation of aphakic cystoid macula edema by vitreous fluorophotometry. Invest Ophthalmol Vis Sci 1981 Suppl; 20: 236.
${ }^{87}$ Curtin VT, Fujino T, Norton EWD. Comparative histopathology of cryosurgery and photocoagulation. Arch Ophihalmol 1966; 75: 674-82.

${ }^{88}$ Stahl JH, Miller V, Conway BP, Campochiaro PA. Dexamethasone and indomethacin attenuate cryopexy induced breakdown of the blood-retinal barrier. Graefes Arch Clin Exp Ophthalmol 1987; 225: 418-20. 